\title{
Influence of ethanol concentration on Scolytinae (Coleoptera: Curculionidae) in a native forest in the municipality of Campo Verde - MT
}

\author{
Influencia de la concentración de etanol en Scolytinae (Coleoptera, Curculionidae) \\ en mata nativa en el municipio de Campo Verde - MT
}

Eliana Santos Alves Bastos ${ }^{1}$, Alberto Dorval2*, Otávio Peres Filho ${ }^{2}$, Marcelo Dias De Souza ${ }^{3}$, Eli Nunes Marques ${ }^{4}$, Josamar Gomes Da Silva Junior ${ }^{1}$

\begin{abstract}
A survey of Scolytinae was carried out in native vegetation in the city of Campo Verde, Mato Grosso, by using 60 ethanolic traps, distributed in six treatments $(\mathrm{T})$ and ten repetitions. With the exception of T4, alcohol was placed in the collection vial. In T1 (control) water, salt and neutral detergent were used; T2 $=25 \%$ alcohol; T3 $=50 \%$ alcohol; T4 (traps with $96 \%$ ethanol in the hose and $70 \%$ in the collection flask); $55=$ alcohol $75 \%$ and $\mathrm{T} 6=$ alcohol $96 \%$. There were 13 genera, 31 species and 7,469 individuals. Hypothenemus eruditus, Xyleborus affinis and Sampsonius dampfi were the most common. Population peaks were more frequent in the dry months of the year.
\end{abstract}

Key words: ethanol concentration, ambrosia-beetle, native forest

\section{RESUMEN}

Se realizó un levantamiento de Scolytinae en vegetación nativa, en el municipio de Campo Verde, Mato Grosso, utilizando 60 trampas etanólicas, distribuidas en seis tratamientos $(T)$ y diez repeticiones. Con excepción de T4, el alcohol se colocó en el frasco colector. En el T1 (Testigo) se utilizó agua, sal y detergente neutro; T2 = alcohol 25\%; T3 = alcohol 50\%; T4 (trampas con etanol a $96 \%$ en la manguera y 70\% en el frasco colector); T5 = alcohol 75\% y T6 = alcohol 96\%. Se produjeron 13 géneros, 31 especies y 7.469 individuos. Hypothenemus eruditus, Xyleborus affinis y Sampsonius dampfi fueron las más expresivas. Los picos poblacionales fueron más frecuentes en los meses secos del año.

Palabras clave: concentración de etanol, escarabajo, bosque nativo

\section{Introduction}

The most commonly used flight traps are funnels with two fins, as they are considered to be more efficient compared to that of one fin used by Montgomery \& Wargo (1983). Fletchamn (1995); Abreu et al. (1997); Dorval \& Peres Filho (2001); Peres Filho et al. (2007); Rocha et al. (2011); Reding et al. (2011) used the model with two fins in studies with Scolytinae in Brazil.
Studies with this group of insects showed that primary attraction in host selection is by olfactory stimulation. In spite of Mclean \& Borden's (1977) assertion that ethanol is more a food stimulant than an attractant, this substance is still the most used in attracting different groups of wood borer beetles. Gil et al. (1985) stated that ethanol may be the main attraction for several species of Xileborini, acting as a synergist between pheromones and the odors released by the hosts, and

\footnotetext{
Postgraduate Program in Forestry and Environmental Sciences, Federal University of Mato Grosso, Cuiabá - MT, Brazil Federal University of Mato Grosso, Faculty of Forestry Engineering, Cuiabá - MT, Brazil.

University of Cuiabá, Cuiabá - MT, Brazil.

Federal University of Paraná, Faculty of Forestry Engineering, Curitiba - PR, Brazil.

Corresponding author: adorval@terra.com.br
}

Fecha de recepción: 21 febrero, 2018.

Fecha de aceptación: 30 junio, 2018.

DOI: 
being totally inefficient in attracting some species of Scolytidae.

Samaniego \& Gara(1970) stated that the efficiency of ethanol varies according to its concentration, despite being a powerful primary attractant for species of the subfamily Scolytinae. Confirming this point, Gil et al. (1985) found that several species of this wood borer beetle subfamily are attracted only to baited traps with low concentrations of ethanol and observed that some species of Scolytidae have preference for high concentration of ethanol. Silva et al. (2006) attributed this variation in the ethanol efficiency to the interference of environmental factors such as climate, wind direction and velocity, spacing and plant age, while Abreu et al. (1997) stated that the amount of plant biomass in the survey area may reduce the attraction power of the traps due to a higher concentration of ethanol produced by decomposing plant material in the environment. The neglect of these factors can lead to errors in the interpretation of results in surveys of Scolytinae using different concentrations of ethanol.

Reding et al. (2011) found differences in numbers of individuals collected in different treatments (ethanol amounts), however, they did not observe significant differences in species diversity among the treatments tested and suggested the development of research with different ethanol concentrations in qualitative and quantitative studies with Scolytinae.

\section{Material and Methods}

The study was carried out in the District of Coronel Ponce, in the region of Capim Branco, located $20 \mathrm{~km}$ from the municipality of Campo Verde, via MT 344 , near geographic coordinates $15^{\circ} 33^{\prime} 13^{\prime \prime} \mathrm{S}$ and $55^{\circ} 09^{\prime} 19^{\prime \prime} \mathrm{E}$. The annual temperature varies between $18^{\circ} \mathrm{C}$ and $24^{\circ} \mathrm{C}$, with the Aw climate having two defined seasons, the dry season (May to September) and the rainy season (October to April). The annual precipitation is $1,750 \mathrm{~mm}$, the predominant soil type is alic, Red-Yellow latosol (Oxisol), and the phyto-physiognomy of the region is composed of grassy-woody savanna vegetation.

Collections were made monthly from July, 2011 to August, 2012 with the use of ethanolimpact traps using a modified bark beetle-Curitiba model, replacing the aluminum impact plate with a transparent 2-liter pet bottle plate. Except for the T4 treatment, the bait holder (alcohol hose) was removed, the collection flasks remaining with the diluted concentrations. Sixty traps were used in six treatments and ten replicates per treatment, each concentration considered as a treatment with the exception of the control. The traps were installed at $1.5 \mathrm{~m}$ from the soil surface with average distance between traps of 30 meters and 200 meters between treatments (Figure 1).

The statistical design was completely randomized with six treatments: $\mathrm{T} 1(\mathrm{Control})=$ water + salt + neutral detergent; $\mathrm{T} 2=25 \%$ ethanol; $\mathrm{T} 3=50 \%$ completely randomized; $\mathrm{T} 4=$ conventional bark beetle-Curitiba traps with $96 \%$ ethanol in the bait holder and $70 \%$ in the collection flask; T5 $=75 \%$ and $\mathrm{T} 6=96 \%$ ethanol. In the analysis of variance the Skott \& Knott test was used, with 5\% probability to detect possible differences between ethanol concentrations and treatments. The program used was SISVAR 5.1, in a factorial system with significance level of 5\%. Considering the binomial distribution and the existence of data with zero values, the data were transformed using the square root of $x+0,5$. In the study of population fluctuation only taxa identified at the species level were considered, which occurred more frequently than $10 \%$ in relation to the general total of individuals collected in all treatments analyzed.

\section{Results and Discussion Qualitative and quantitative analysis}

In the six treatments 7,469 individuals were collected belonging to 12 genera and 31 species, which differs from the results obtained by Dorval et al. (2001) and Rocha et al. (2011b) with Scolytinae in Cerrado vegetation developed in the region. The treatments $\mathrm{T} 3$, T5 and T4 were the most diversified in number of species. In relation to the number of individuals, T5 with 3,022 (40,46\%), T4 with 1,807 (24,19\%) and T3 with 1,539 (20,61\%) were quantitatively the most representative (Tables 1 and 2). Although 96\% ethanol as an attractant is the most used in studies with this group of insects, the use of other concentrations in quantitative monitoring can provide better results with lower financial cost.

Xyleborus, Cryptocarenus, Corthylus and Hypothenemus were the genera with most species. In relation to the number of individuals collected, T5 $(40,46 \%), \mathrm{T} 4(24,19 \%)$ and T3 $(20,61 \%)$ were quantitatively the most representative (Tables 1 and 2). The predominance of species and individuals of these groups of insects in plantations of Eucalyptus spp. and in Eucalyptus hybrids were observed Peres 


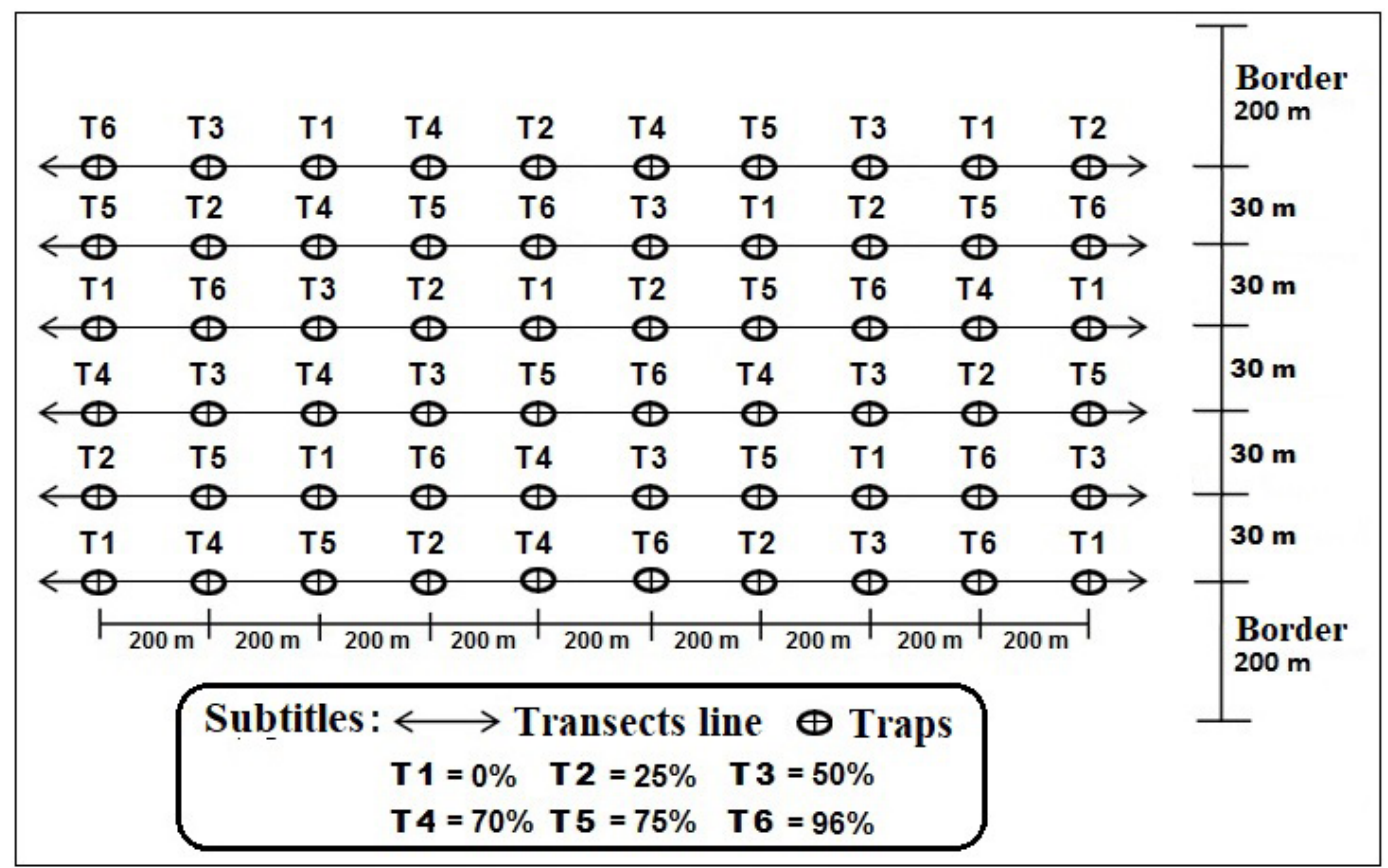

Figure 1. Sketch of the distribution of ethanol traps by treatment in the study area. Campo Verde, MT, 2011/2012.

Table 1. Quantities (QT) and percentages (\%) of coleopteran species and numbers collected with ethanol traps in T1, T2 and T3 treatments. Campo Verde, MT. 2011.

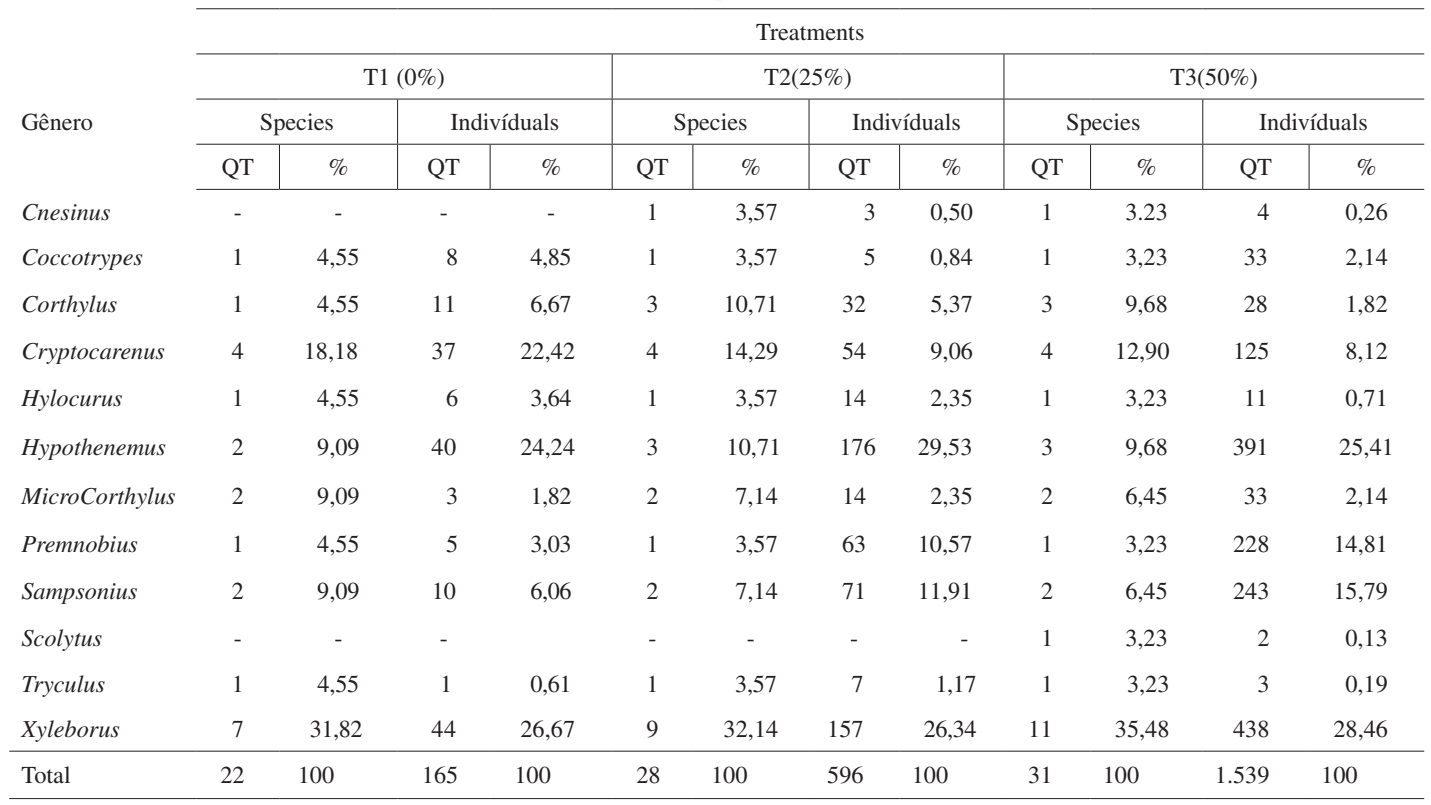


Table 2. Quantities (QT) and percentages (\%) of species and numbers of coleopterans collected with ethanol traps in T4, T5 and T6 treatments. Campo Verde, MT. 2011.

\begin{tabular}{|c|c|c|c|c|c|c|c|c|c|c|c|c|}
\hline \multirow{3}{*}{ Gênero } & \multicolumn{4}{|c|}{$\mathrm{T} 4(70 \%)$} & \multicolumn{4}{|c|}{ T5 $(75 \%)$} & \multicolumn{4}{|c|}{ T6(96\%) } \\
\hline & \multicolumn{2}{|c|}{ Species } & \multicolumn{2}{|c|}{ Indivíduals } & \multicolumn{2}{|c|}{ Species } & \multicolumn{2}{|c|}{ Indivíduals } & \multicolumn{2}{|c|}{ Species } & \multicolumn{2}{|c|}{ Indivíduals } \\
\hline & QT & $\%$ & QT & $\%$ & QT & $\%$ & QT & $\%$ & QT & $\%$ & QT & $\%$ \\
\hline Coccotrypes & 1 & 3.45 & 41 & 2.27 & 1 & 3.33 & 35 & 1.16 & 1 & 4.17 & 1 & 0.29 \\
\hline Corthylus & 2 & 6.90 & 16 & 0.89 & 3 & 10.00 & 22 & 0.73 & 1 & 4.17 & 4 & 1.18 \\
\hline Hylocurus & 1 & 3.45 & 23 & 1.27 & 1 & 3.33 & 33 & 1.09 & 1 & 4.17 & 8 & 2.35 \\
\hline Hypothenemus & 3 & 10.34 & 309 & 17.10 & 3 & 10.00 & 656 & 21.71 & 3 & 12.50 & 82 & 24.12 \\
\hline MicroCorthylus & 2 & 6.90 & 55 & 3.04 & 2 & 6.67 & 61 & 2.02 & 2 & 8.33 & 10 & 2.94 \\
\hline Premnobius & 1 & 3.45 & 136 & 7.53 & 1 & 3.33 & 230 & 7.61 & 1 & 4.17 & 29 & 8.53 \\
\hline Tryculus & 1 & 3.45 & 19 & 1.05 & 1 & 3.33 & 27 & 0.89 & 1 & 4.17 & 2 & 0.59 \\
\hline Xyleborus & 10 & 34.48 & 592 & 32.76 & 10 & 33.33 & 1.036 & 34.28 & 9 & 37.50 & 102 & 30.00 \\
\hline Total & 29 & 100 & 1.807 & 100 & 30 & 100 & 3.022 & 100 & 24 & 100 & 340 & 100 \\
\hline
\end{tabular}

Filho et al. (2007); Rocha et al. (2011). According to Dorval et al. (2004), many species of the genus Cryptocarenus, Hypothenemus and Xyleborus are considered secondary pests, however in these genera there are species with potential to cause considerable damage in areas with commercial plantations; the phytosanitary status will decisively influence the population density of the pest species within the planted areas.

The frequent occurrence of species of Hypothenemus and Cryptocarenus species is justified, as these species attack small branches, branches and fruits of native species that are very abundant in this type of vegetation. Hypothenemus species are primarily bark drillers or sprouts, but some species can attack fruits, seeds and twigs and branches of small diameters (Beaver, 1974). Xyleborus is considered the most important and most diversified genus in the Neotropical region, as it encounters a large number of potential hosts in this type of forest environment, in addition to adapting to the climatic conditions in this region. According to Chandra (1981), several species of the genus Xyleborus constitute one of the most destructive groups of wood drillers within Scolytinae, attacking live trees and freshly cut wood, causing permanent damage by opening galleries and by the staining of the wood caused by the symbiotic fungus.

Among the species common to all treatments, $H$. eruditus, X. afinnis, S. dampfii and P. cavipennis had the largest number of individuals collected. According to Wood (1982), H. eruditus has a wide variety of hosts and its food habit depends on the source of food available. In the study area, 21 species were common to all treatments, showing that depending on the objective of the study, the use of alcohol as an attractive is optional, because factors such as favorable environmental conditions and food availability will determine the presence or absence of these species. Ethanol played a key role in the attraction of $C$. papulans, $H$. bolivianus and $X$. compactus independent of concentration, while the species $C$. drygraphus, $C$. nudipennis, $S$. dentactus, S. multistriatus, X. ferrugineus, X. retusus and $X$. tolimanus showed preferences for determined concentrations of ethanol (Table 3).

Some species of Scolytinae considered to be pests, suchas H. eruditus, X. afinnis, S. dampfii,C.nudipennis, $\mathrm{X}$. spinolosus and $P$. cavipennis, are normally abundant in this type of environment. They were also collected in T1 (water + salt + neutral detergent), showing that depending on the objective of the study, the presence or absence of individuals of these species is independent of ethanol.

The species $C$. drygraphus, C. papulans, $H$. bolivianus, $S$. multistriatus, $X$. compactus, $X$. ferrugineus, $X$. retusus and $X$. tolimanus were not collected in $\mathrm{T} 1$ (water + salt + neutral liquid detergent), showing that alcohol plays a key role in attracting these species. H. bolivianus and $X$. compactus occurred in all treatments containing alcohol, regardless of concentration, whereas in C. drygraphus, C.papulans, $S$. multistriatus, $X$. ferrugineus, $X$. retusus and $X$. tolimanus, the concentration of the attractant was 


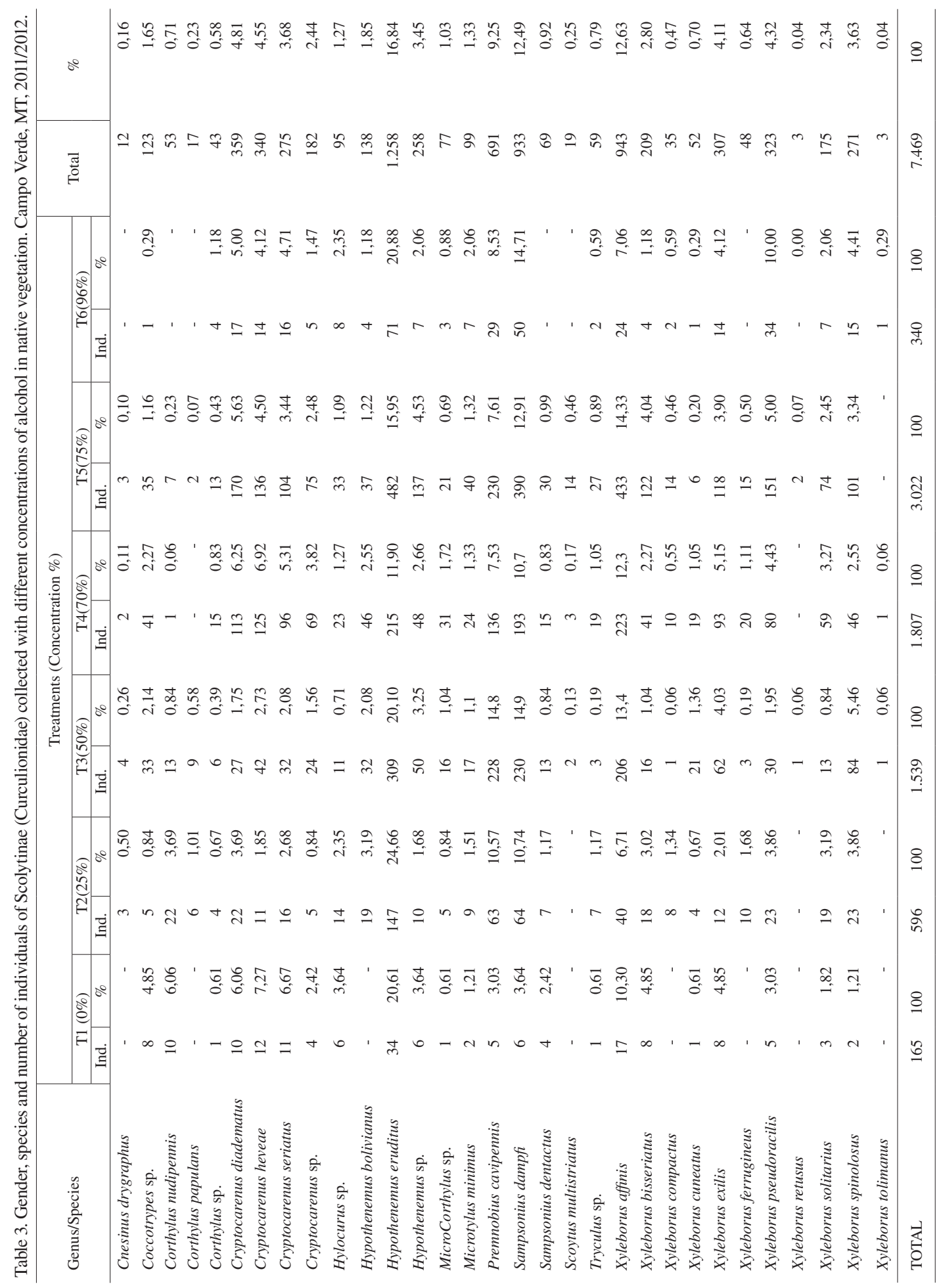


determinant for the numbers of individuals collected. The species $C$. nudipennis and $S$. dentactus, although occurring in the T1 treatment, showed that alcohol, depending on the concentration, can be used as an attractive for their sampling in this type of environment (Table 3). H. eruditus was the most representative species in number of individuals collected in all treatments tested. These results resemble those obtained by Carvalho et al. (1996), who found that $34.17 \%$ individuals collected in native vegetation were of $H$. eruditus.

$X$. affinnis in treatments $\mathrm{T} 1, \mathrm{~T} 4$ and $\mathrm{T} 5$ and $S$. dampfi in treatments $\mathrm{T} 2, \mathrm{~T} 3$ and $\mathrm{T} 6$ had the largest number of individuals collected. The individualized analysis of the treatments showed that $H$. eruditus and $X$. affinis in T1, H. eruditus, S. dampfi, P. cavipennis in T2, H. eruditus, S. dampfi, P. cavipennis, X. affinis in T3, X H. eruditus, S. dampfi in T4, H. eruditus, $X$. affinis, S. dampfi, in T5 and H. eruditus, S. dampfi and $X$. pseudoracillis in T6 had the largest numbers of specimens collected (Table 3 ).

The smallest number of individuals collected was observed treatments T1 (without alcohol) and T6 (pure alcohol), showing that some species of bark beetle can be collected in traps without the use of pure alcohol as attractive. Studies using impact traps with different concentrations of alcohol or only preservative (water + salt + neutral detergent) in the collection flask can be considered an advance for new studies with this group of insects, due to the difficulty of obtaining pure commercial alcohol, which is the concentration most used in research in different forest environments.

\section{Statistical analysis}

There were statistically significant differences between the population average of Scolytinae species among treatments and significant interaction between concentration and insect species (Table 4). Scolytinae species with potential to cause economic damage in the forest area presented different behavior in relation to the treatments. C. nudipennis presented a statistically significant difference in T4 in relation to the other treatments. H. eruditus presented statistically significant differences among all the treatments tested. P. cavipennis, did not significant differences between T3 and T5 treatments. S. dampfii did not show significant differences between $\mathrm{T} 3$ and $\mathrm{T} 4$ or between $\mathrm{T} 2$ and T6.X. affinnis did not have significant difference only between treatments $\mathrm{T} 2$ and $\mathrm{T} 3$ (Table 5).

The species H. eruditus, C. heveae, Tricolus sp. and $X$. bisseriatus did not have significant differences in T1 (Table 5). In T2, H. eruditus was significantly different from the other species. P. cavipennis, $S$. dampfi and $X$. affinis showed high average numbers of individuals and did not present significant differences, whereas in T3 H. eruditus had significant differences in relation to the other species. P. cavipennis and $S$. dampfi did not show significant differences. In the T4 treatment, $H$. eruditus, $S$. dampfi and X. affinis also did not present significant differences, followed by $C$. nudipennis, $C$. heveae, C. seriatus, $P$. cavipennis and $X$. ferrugineus with the highest averages, but without significant differences between them (Table 5).

H. eruditus differentiated significantly from the other species in the $\mathrm{T} 5$ treatment, while in $\mathrm{T} 6$ $H$. eruditus and $S$. dampfi showed no significant difference, followed by $P$. cavipennis and X. affinis, which had a significant difference. The species $H$. eruditus occurred in all treatments with high averages and with significant differences among treatments, showing that despite having occurred as a constant in all treatments it was evident that their populations were affected by the concentrations of the attractant used (Table 5). It is noteworthy that the T4 treatment may have been more efficient in relation to the other

Table 4. Analysis of variance of the species, concentration and species $\mathrm{x}$ ethanol concentration interaction factors for the population of Scolytinae (Curculionidae) in an area with native vegetation. Campo Verde, MT, 2011/2012.

\begin{tabular}{lr|r|r|r|c}
\hline \multicolumn{1}{c|}{ FV } & GL & \multicolumn{1}{c|}{ SQ } & \multicolumn{1}{c|}{ QM } & \multicolumn{1}{c}{ Fc } & Pr>Fc \\
\hline Species & 31 & 1170,182075 & 37,747809 & 92.478 & $0,0000^{* *}$ \\
Concentration & 5 & 632,754904 & 126,550981 & 310.035 & $0,0000^{* *}$ \\
Species x Concentration & 155 & 701,959059 & 4,528768 & 310.035 & $0,0000^{* *}$ \\
Error & 1728 & 705,341056 & 0,408183 & & \\
Total correted & 1919 & 3210,237095 & & & \\
\hline CV $(\%)=$ & \multicolumn{7}{c}{38,88} \\
\hline
\end{tabular}

$(* *)$ - Significant at the $1 \%$ probability level by the $\mathrm{F}$ test. 


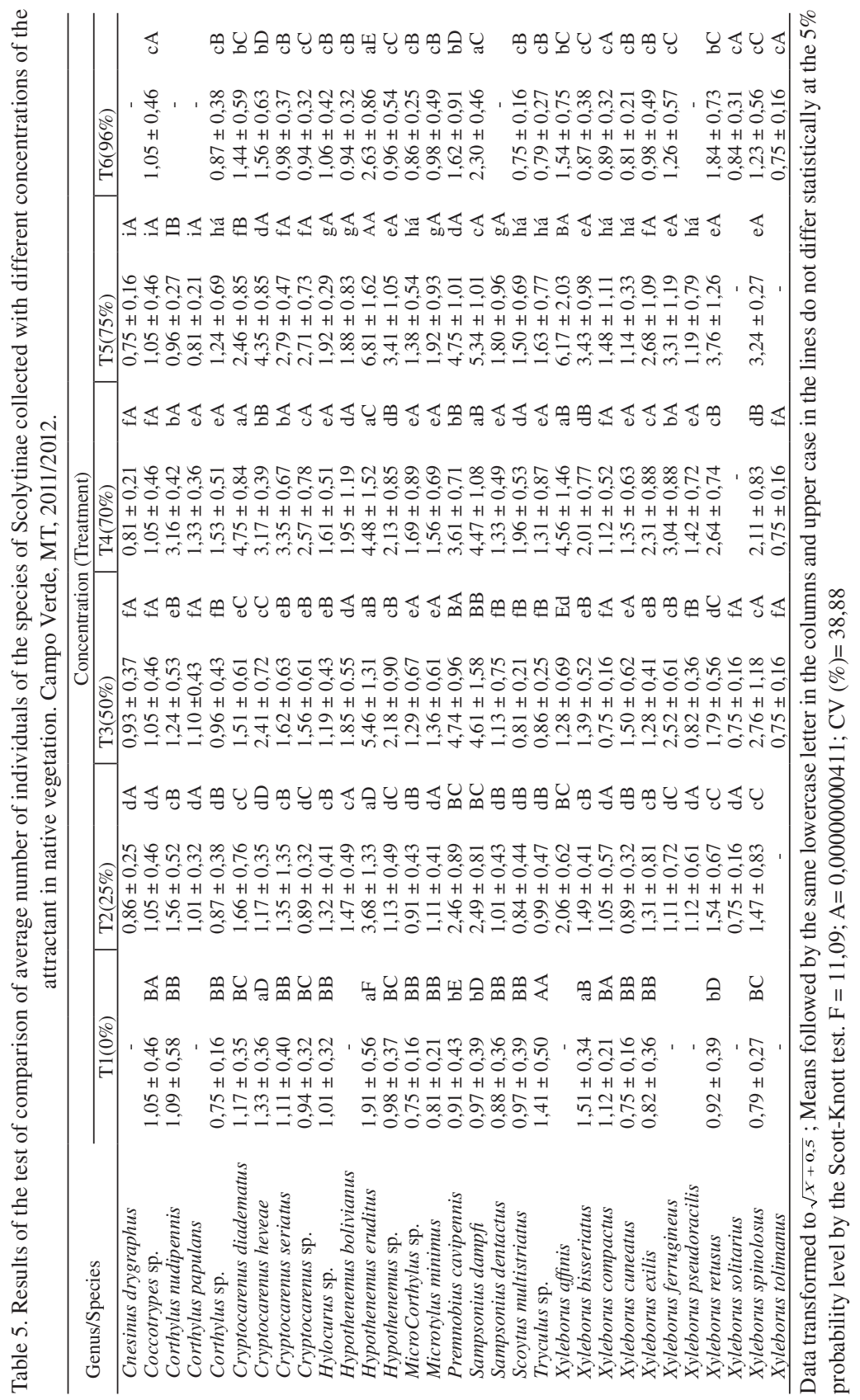


treatments that used alcohol only in the bait holder, due to the presence of two sites containing attractive substances, which may have increased the attraction power of the traps for certain species of Scolytinae.

\section{Population fluctuation}

The smallest number of individuals occurred both during the rainy season and during the dry season. H. eruditus occurred with population peaks in September, December, February, May and July. Rocha et al. (2011) observed a population peak of $H$. eruditus in plantations of Eucalyptus camaldulensis. X. affinis showed population peaks in September, March and July; Rocha et al. (2011) observed population peaks of this species in E. camaldulensis plantations in June and October. $S$. dampfi had population peaks in August, October and July (Figure 2). These species are apparently adapted to the end of the rainy season and the months of low rainfall in the study region.

\section{Conclusions}

- The use of ethanol is important in Scolytinae sampling.

- Ethanol in different concentrations is efficient in the sampling of Scolytinae in native environments.

- Several species of Scolytinae can be sampled without the use of ethanol.

- The use of $96 \%$ ethanol (T6) did not present superior results to the other treatments used.

- The species Hypothenemus eruditus, Sampsonius dampfi andXyleborus afinnis showed more population peaks in the months considered dry in this region.

\section{Acknowledgment}

To the Postgraduate Program in Forestry and Environmental Sciences / FENF / UFMT for the opportunity and CAPES for the scholarship for the development of this study.

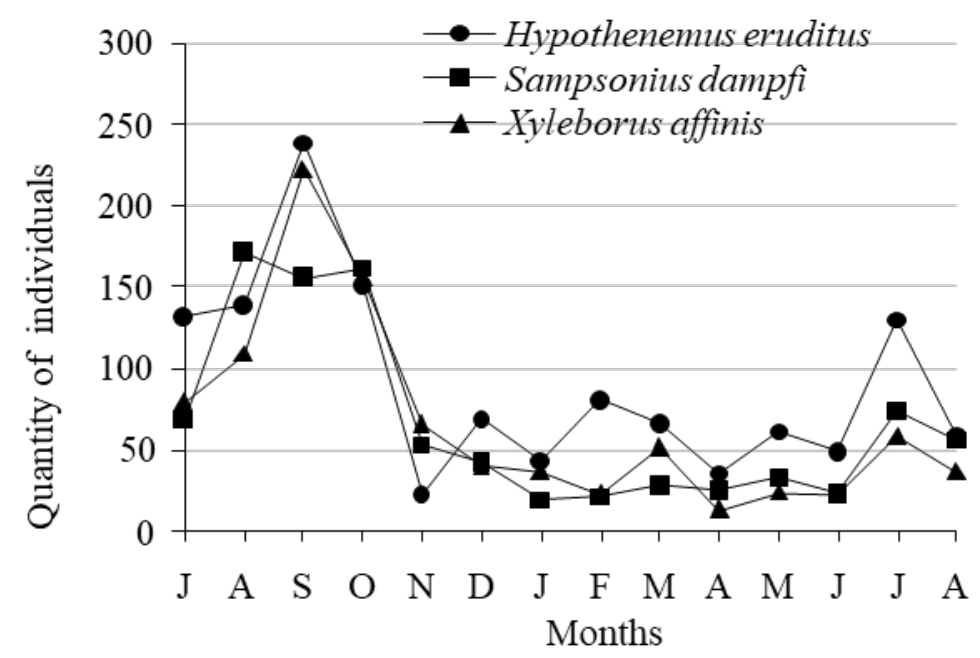

Figure 2. Population fluctuation of Hypothenemus eruditus, Sampsonius dampfii and Xyleborus affinis (Scolytinae: Curculionidae) in native vegetation in the municipality of Campo-Verde, Mato Grosso. 2011. 


\section{Literature Cited}

Abreu, R.L.S.; Fonseca, C.R.; Marques, E.N.

1997. Análise das principais espécies de Scolytidae coletadas em floresta primária no estado do Amazonas. Anais da Sociedade Entomológica do Brasil, 26 (3): 527-35.

Beaver, R.A.

1974. Biological studies of Brazilian Scolytidae and Platypodidae (Coleoptera). IV. The tribe Cryphalini. Studies on the Neotropical Fauna, 9 (1): 171-178.

Chandra, A.

1981. Bioecology of wood destroying Xyleborus and their control (Insecta:Scolytidae). Indian Journal of Forestry, 4 (1): $286-289$.

Carvalho, A.G.; Rocha, M.P.; Lunz, A.M.

1996. Variação sazonal de Scolytidae (Coleoptera) numa comunidade de floresta natural de Seropédica, RJ. Floresta e Ambiente, 3 (1): 9-14.

Dorval, A.; Peres Filho, O.

2001. Levantamento e flutuação populacional de coleópteros em vegetação do cerrado da baixada Cuiabana, MT. Ciência Florestal, 11 (2): 171-182.

Dorval, A.; Peres Filho, O.; Marques, E.N.

2004. Levantamento de Scolytidae (Coleoptera) em plantações de Eucalyptus spp., em Cuiabá, estado de Mato Grosso. Revista Ciência Florestal, 14 (1): 47 - 58.

Flechtman, C.A.H. (COORD.)

1995. Manual de pragas em florestas - Scolytidae em reflorestamento com pinheiros tropicais, PCMIP/IPEF, 1 (1): 1-201.

Gil, J.; Pajares, J.; Viedma, M.G.

1985. Estudios acerca de la atracción primária en Scolytidae (Coleoptera) parasitos de coníferas. Boletín de la Estacion Central de Ecologia, 14 (27): 107-125.
Montgomery, M.E.; Wargo, P.M.

1983. Ethanol and other host-derived volatiles as attractants for beetles that bore into hardwoods. Journal of Chemical Ecology, 9 (2): 181-190.

Mclean, J.A.; Borden, J.H.

1977. Attack by Gnathotrichus sulcatus (Coleoptera: Scolytidae) on stumps and felled trees baited with sulcatol and Ethanol. The Canadian Entomologist, 109 (1): 675-686.

Peres Filho, O.; Dorval, A.; Noquelli, M.J.M.S.

2007. Coleópteros em plantio de Eucalyptus camaldulensis no estado de Mato Grosso. Revista Floresta e Ambiente, 14 (1): 45-51.

Reding, M.E.; Schultz, P.B.; Ranger, C.M. Olivier, J.B.

2011. Optimizing ethanol-baited traps for monitoring damaging ambrosia beetles (Coleptera:Curculionidae, Scolytinae) in ornamental nurseries. Journal of Economic Entomology, 104 (1): 2017-2024.

Rocha, J.R.M.; Dorval, A.; Peres Filho, O.; Souza, M.D. Costa, R.B.

2011. Análise da ocorrência de Coleópteros em Plantios de Eucalyptus camaldulensis Dehn. em Cuiabá, MT. Floresta e ambiente, 18 (4): 343-352.

Saminiego, A.V.; Gara, R I.

1970. Estúdios sobre la actividad de vuelo y selection de húespedes por Xyleborus y Platypus spp. (Coleoptera: Scolytidae y Platypodidae). Turrialba, 20 (4): 471-477.

Silva, F.C.; Ventura, M.U.; Morales, L.

2006. Capture of Hypothenemus hampei Ferrari (Coleoptera, Scolytidae) in response to trap characteristics. Scientia Agricola, 63 (1): 567-571.

Wood, S.L.

1982. The bark and ambrosia beetles of North and Central America (Coleoptera: Scolytidae), a taxonimic monograph. Great Basin Naturalist Memoirs, Provo, 6 (1): 1-1361. 